\title{
Analisis Karakteristik dan Potensi Tingkat Erosi Daerah Aliran Sungai Blorong Kabupaten Kendal Tahun 2013 dan 2018 Menggunakan Sistem Informasi Geografis dan Pendekatan Universal Soil Lost Equation (USLE)
}

\author{
Achmad Zakky Robbany ${ }^{1 *}$, Dhea Sarah Setyorini ${ }^{1}$, Aldino Maulana Riski ${ }^{1}$, Santhi Widyastuti ${ }^{1}$ \\ ${ }^{1}$ Departemen Teknik Geologi, Fakultas Teknik, Universitas Diponegoro, \\ Jl. Prof. Soedarto, SH Tembalang, Semarang
}

\begin{abstract}
Abstrak
Peningkatan penduduk yang pesat mengakibatkan suatu daerah terus berkembang, salah satunya yaitu berada di Daerah Aliran Sungai (DAS) Blorong. DAS Blorong dengan luas area 208,20 km² merupakan salah satu sub DAS bagian timur dari DAS Bodri-Kuto yang berada di kabupaten Semarang dan kabupaten Kendal. Penelitian memiliki tujuan untuk mengetahui karakteristik dan tingkat erosi di DAS Blorong. Metode yang digunakan untuk menghitung tingkat erosi di DAS Blorong yaitu menggunakan USLE (Universal Soil Loss Equation). Metode USLE yang dilakukan dengan Sistem Informasi Geografis (SIG) dengan mencari faktor-faktor untuk mendapatkan nilai USLE tersebut, beserta menganalisa karakteristik DAS dari data digital elevation model (DEM), peta tata guna lahan, peta geologi, dan curah hujan (tahun 2013 dan 2018). Pada DAS Blorong ditentukan karaktersitiknya berdasarkan hulu dan hilir dari DAS tersebut. Tingkat erosi yang terdapat pada DAS Blorong ditinjau dari tata guna lahan di DAS tersebut. Tingkat erosi di DAS Blorong pada tahun 2013 hingga 2018 terjadi peningkatan sebesar $10,78 \%$, dari $852,236,26$ ton/Ha/tahun menjadi $944.037,79$ ton/Ha/tahun. Berdasarkan identifikasi dan perhitungan, menunjukkan bahwa curah hujan dan perubahan lahan pemukiman, agrikultur, dan ladang merupakan penyumbang terbesar erosi. Rekomendasi yang dapat dilakukan untuk meminimalisir potensi erosi adalah berupa upaya konservasi pada wilayah ini.
\end{abstract}

Kata Kunci: DAS Blorong; Erosi; Kendal; SIG;USLE.

\begin{abstract}
A rapid increase in population causes an area to continue to grow, one of which is located in the Blorong watershed. The Blorong watershed, that covers $208.2 \mathrm{~km}^{2}$ area, is one of the eastern sub-watersheds of the Bodri-Kuto watershed located in Semarang district and Kendal district. The research aims to determine the characteristics and the level of erosion in the Blorong watershed. The method used to calculate the level of erosion in the Blorong watershed is USLE (Universal Soil Loss Equation). The calculation is performed by a Geographic Information System (GIS) by finding factors along with analyzing the characteristics of the watershed from Digital Elevation Model (DEM), land use map, geological map, and rainfall data (2013 and 2018). In Blorong watershed the characteristics are determined based on upstream and downstream of the watershed. The level of erosion in Blorong watershed is based on the land use. The level of erosion in the Blorong watershed in 2013 to 2018 has increased by $10.78 \%$ from 852,236.26 ton/Ha/year to 944,037.79 ton/Ha/year. The main factors of erosion are rainfall, land use transformation of agriculutural land and residential area. Conservations are needed to minimize the erotional petention in this area.
\end{abstract}

Keyword: Blorong Watershed; Erosion; Kendal; GIS;USLE.

\section{PENDAHULUAN}

Peningkatan penduduk yang pesat mengakibatkan suatu daerah terus berkembang. Peningkatan tersebut diselingi dengan aktivitas penduduk yang berlangsung sangat cepat dapat mengakibatkan semakin berkurangnya tataguna lahan secara signifikan, terutama pada wilayah Daerah Aliran Sungai (DAS).

Perubahan tataguna lahan yang dahulunya berfungsi sebagai penjaga keseimbangan lingkungan DAS kini menimbulkan persoalan

\footnotetext{
${ }^{*}$ Korespondensi: achmadrby@students.undip.ac.id
} 
berupa erosi. Informasi mengenai tingkat erosi sebuah DAS menjadi penting karena dapat menjadi indikator untuk dapat melakukan tata kelola pada tata guna lahan di sekitar DAS.

DAS Blorong (Gambar 1), yang terletak di $109^{\circ} 40^{\prime}-110^{\circ} 18^{\prime}$ BT dan $6^{\circ} 32^{\prime}-7^{\circ} 24^{\prime}$ LS melewati dua daerah administratif, yaitu Kabupaten Kendal dan Kota Semarang, Provinsi Jawa Tengah, dengan luas DAS mencakup area seluas $208,20 \mathrm{~km}^{2}$. Kedua daerah administratif tersebut sudah merupakan area vital dalam pembangunan provinsi, sehingga tata guna lahan sudah pasti banyak mengalami perubahan yang dapat mempengaruhi tingkat erosi DAS Blorong.

Universal Soil Loss Equation (USLE) adalah pendekatan untuk mengestimasi potensi erosi berdasarkan 4 faktor, yaitu erosivitas hujan, erodibilitas tanah, panjang dan kemiringan lereng, dan tutupan lahan (Anggoro dkk., 2018). Pendekatan USLE sendiri belum pernah diaplikasikan pada DAS Blorong. Berdasarkan alasan tersebut yang melatarbelakangi penulisan penilitian untuk mengestimasi tingkat erosi di
DAS Blorong. Tujuan penelitian ini adalah untuk mengetahui karakteristik dari DAS Blorong serta mengetahui tingkat erosi yang terjadi pada tahun 2013 dan tahun 2018 pada DAS Blorong berdasarkan data curah hujan dan keterdapatan tata guna lahan yang berada pada DAS tersebut.

\section{METODOLOGI}

A. Analisis kelerengan

Peta kemiringan lereng di lokasi penelitian diperoleh berdasarkan analisis citra Digital Elevation Model yang diklasifikasikan menjadi lima kelas yaitu $0-8 \%$; 9-15\%; 16-25\%, 26-45\%; $46-100 \%$.

B. Perhitungan tingkat bahaya erosi

Proses perhitungan analisis tingkat bahaya erosi yaitu dengan menggunakan rumus USLE dari Wischmeier dan Smith (1978) yang nilai parameter faktornya dapat diperoleh melalui Sistem Informasi Geografis (SIG) (Setyawan dkk., 2017). Faktor yang menjadi input dalam formulasi USLE adalah:

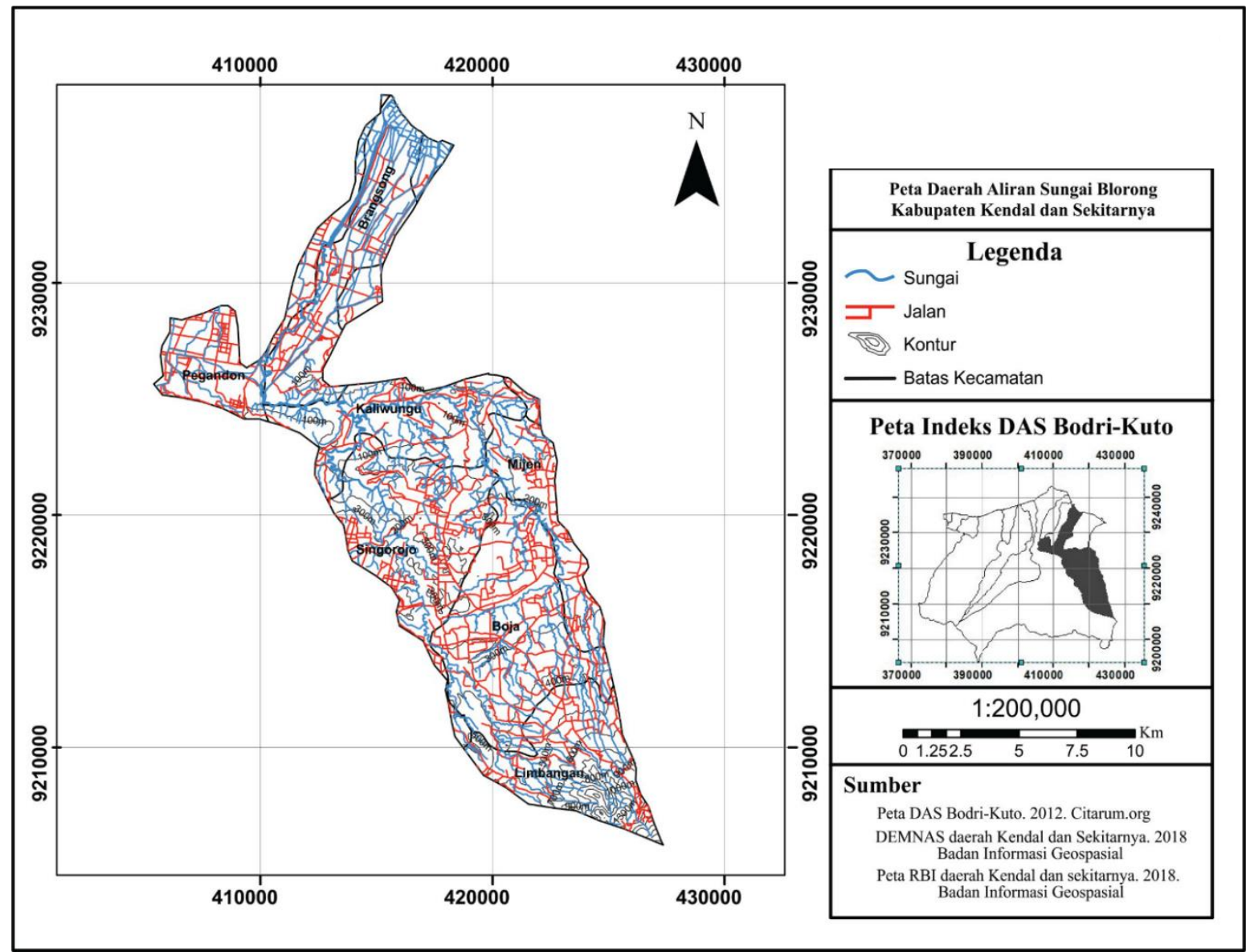

Gambar 1. Peta Wilayah DAS Blorong 
1. Karakteristik daerah aliran sungai (DAS). Karakteristik daerah aliran sungai merupakan salah satu proses pengalihragaman hujan yang jatuh pada suatu daerah aliran di alur sungai.

2. Pengaruh parameter fisik DAS terhadap karakteristik aliran terdiri dari bentuk Das, luas DAS, Topografi dan Geologi, kerapatan jaringan sungai/Indeks keraptan sungai serta tataguna lahan.

3. Indeks erosivitas (R). Indeks erosivitas hujan merupakan kemampuan hujan yang dapat menyebabkan erosi, terutama oleh air (Yin dkk.,2005; Oliviera dan Nearing, 2012). Data curah hujan yang digunakan adalah dari tiga stasiun curah hujan yaitu Stasiun Ketapang, Stasiun Kedung Pucung dan Stasiun Limbangan selama tahun 2013 dan 2018 dengan menggunakan rumus: $\mathrm{R}=0,01 \Sigma \mathrm{i}$ $(916+331 \log \mathrm{i})$, dimana $\mathrm{i}$ adalah intensitas hujan dalam inci per jam

4. Indeks erodibilitas tanah (K). Indeks erodibilitas tanah menunjukkan tingkat kerentanan tanah terhadap erosi, yaitu retensi partikel terhadap pengikisan dan perpindahan tanah oleh energi kinetik air hujan (Hammer, 1981).

5. Indeks panjang dan kemiringan lereng (LS). Faktor panjang dan kemiringan lereng (LS) terdiri dari dua komponen, yakni faktor panjang lereng dan faktor kemiringan lereng yang dapat ditentukan berdasarkan peta kemiringan lereng.

6. Indeks penutupan vegetasi dan pengolahan lahan (CP). Faktor penutupan vegetasi dan pengolahan lahan menggambarkan dampak kegiatan pertanian dan pengolahannya terhadap tingkat erosi (Wischmeier \& Smith, 1978).

7. Erosi Tanah. Laju erosi tanah diprediksi menggunakan rumus USLE (Wischmeier dan Smith, 1978). Formulasi USLE adalah sebagai berikut:

\section{$A=R \times K \times L \times S \times C \times P$}

Keterangan :

$\mathrm{A}=$ Laju erosi tanah (ton/ha/tahun) $\mathrm{R}=$ Indeks erosivitas hujan

$\mathrm{K}=$ Indeks erodibilitas tanah

$\mathrm{L}=$ Indeks panjang lereng

$\mathrm{S}=$ Indeks kemiringan lereng

$\mathrm{C}=$ Indeks penutupan vegetasi

$\mathrm{P}=$ Indeks pengolahan lahan atau tindakan konservasi tanah

\section{HASIL}

A. Karakteristik DAS

Berdasarkan kenampakan di lapangan dapat diketahui bahwa parameter fisik DAS terhadap karakteristik aliran pada jalur sungai di DAS Blorong, yaitu topografi, kondisi geologi, bentuk dan luas DAS, kerapatan jaringan sungai, dan tataguna lahan.

1. Topografi; pada peta geomorfologi dapat diketahui bahwa daerah penelitian ini termasuk ke dalam bentuk lahan denudasional, struktural serta vulkanik yaitu berupa dataran, perbukitan landai serta bukit bergelombang dan bagian dari kerucut gunungapi diperlihatkan pada Gambar 2. Sehingga dapat dilihat bahwa berdasarkan kenampakan topografi yang dimiliki daerah penelitian ini memiliki alur sungai yang besar dan debit puncak yang besar, ditunjukkan dengan aliran permukaan yang cepat pada daerah morfologi yang memiliki kemiringan besar.

2. Geologi; faktor geologi menjadi salah satu faktor dalam menentukan besarnya laju infiltrasi dan evaporasi yang terjadi pada suatu DAS. Karakteristik geologi daerah penelitian ini ditinjau dari peta geologi (Gambar 3), selanjutnya dikelompokkan menjadi dua karakteristik permeabilitas batuan yaitu terdapat daerah dengan permeabilitas yang besar terdapat pada daerah hulu sungai sehingga proses infiltrasi yang terjadi cukup besar dan potensi aliran permukaan yang terjadi kecil. Sedangkan pada daerah hilir sungai terdapat permeabilitas batuan yang cukup kecil sehingga menyebabkan aliran permukaan yang cukup besar dikarenakan daerah infiltrasi yang dimiliki yaitu kecil.

3. Bentuk DAS; pada daerah penelitian memiliki bentuk yang memanjang oleh sebab itu waktu untuk terjadinya akumulasi aliran penuh akibat curah hujan akan lebih lama.

4. Luas DAS; luasan pada DAS Blorong sebesar $208,20 \mathrm{~km}^{2}$ sehingga menyebabkan faktor losses dan reduksi akibat aliran debit puncak yang dimiliki pada DAS Blorong ini. 
5. Kerapatan jaringan sungai; dinyatakan dengan panjang alur sungai per satuan luas DAS. Pada DAS Blorong ini jaringan kerapatan sungai yang dimiliki yaitu besar dengan penciri terdapatnya anak sungai yang cukup banyak sehingga proses pengatusan lebih cepat, sebab air limpasan permukaan akan segera tertampung pada alur-alur sungai.

6. Tataguna lahan, faktor tataguna lahan merupakan salah satu faktor yang memiliki pengaruh dominan pada karakteristik DAS dikarenakan dapat diketahui besarnya losses akibat infiltrasi dan besarnya koefisien limpasan permukaan (koefisien aliran). Pada daerah penelitian ini berdasarkan peta tataguna lahan (Gambar 5) yang dimiliki diketahui bahwa sebagian besar daerah penelitian ini diperuntukkan sebagai sawah serta perkebunan yang cukup luas sehingga nilai koefisisan limpasan permukaan (koefisien aliran) tidak melebihi ambang batas.

\section{B. Indeks Erosivitas}

Berdasarkan perhitungan indeks erosivitas curah hujanpada tahun 2013 dan tahun 2018 dengan menggunakan rumus $\mathrm{R}=0,01 \Sigma \mathrm{i}(916+331 \log \mathrm{i})$ diperoleh nilai seperti yang dapat dilihat pada Tabel 2.

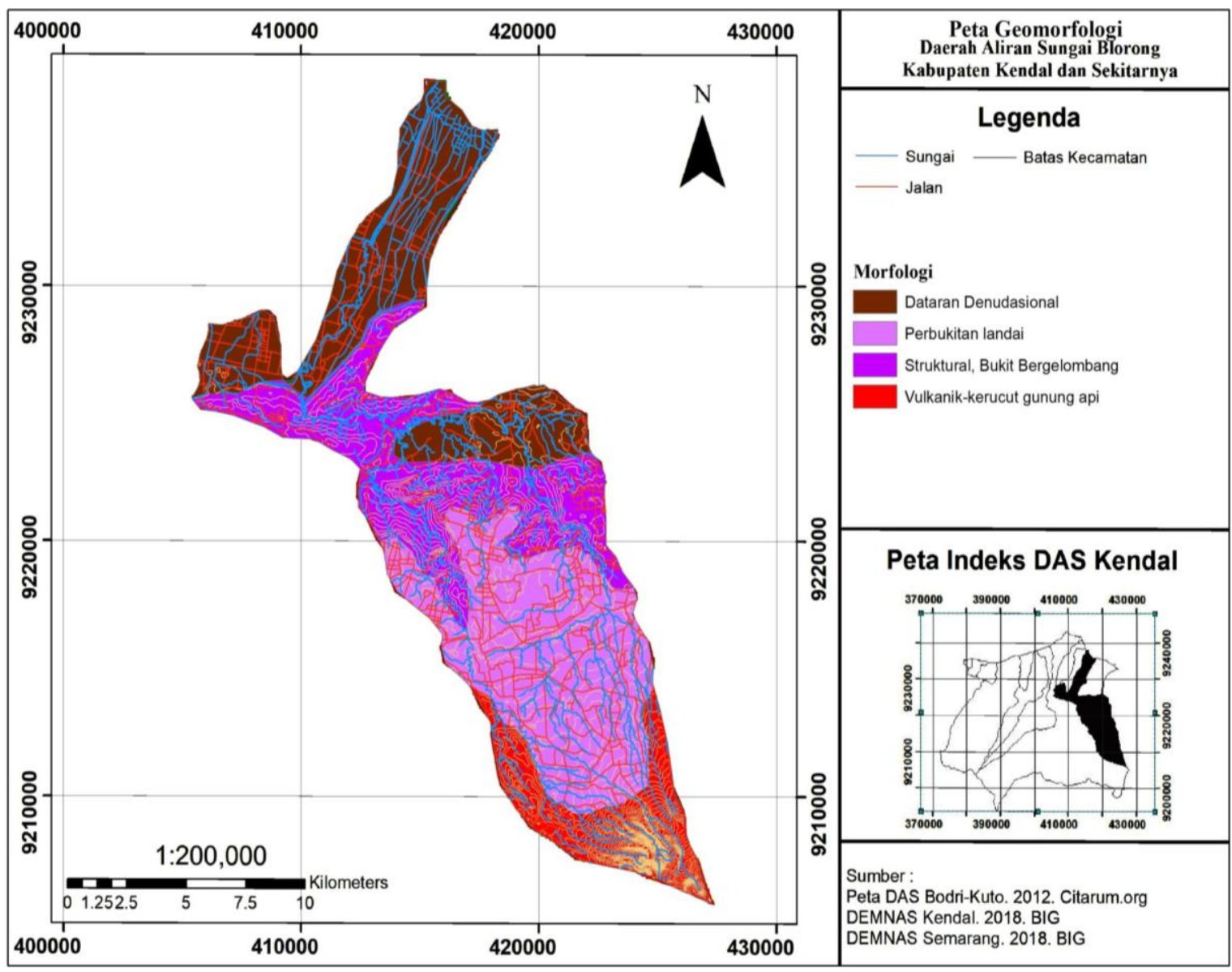

Gambar 2. Peta Geomorfologi DAS Blorong

Tabel 2. Indeks erosivitas curah hujan Kabupaten Kendal Tahun 2013 dan 2018 (Badan Pusat Statistik Kabupaten Kendal, 2013; Badan Pusat Statistik Kabupaten Kendal, 2018))

\begin{tabular}{ccccc}
\hline Tahun & $\begin{array}{c}\text { Curah hujan } \\
\text { (mm/tahun) }\end{array}$ & $\begin{array}{c}\text { Curah Hujan } \\
\text { (Inch/tahun) }\end{array}$ & $\begin{array}{c}\text { Log } \\
\text { (i) }\end{array}$ & Erosivitas Hujan (R) Inch \\
\hline 2013 & 96 & 3,779527559 & 0,577 & 235,8103596 \\
2018 & 131 & 5,157480315 & 0,712 & 261,1994091 \\
\hline
\end{tabular}


C. Indeks Erodibilitas Tanah

Nilai indeks erodibilitas tanah (K) yang digunakan mengacu pada pengklasifikasian jenis tanah berdasarkan tekstur tanah diperoleh hasil bahwa lokasi penelitian ini terdiri dari jenis tanah loamy sand dan fine sand.

D. Indeks panjang dan kemiringan lereng Menurut Paningbatan, Jr (2001) mencatat bahwa faktor LS dapat juga diturunkan secara bersamaan dari peta persentase kemiringan lahan (S) yang dihasilkan dengan menggunakan peta elevasi digital (Digital Elevation Model), berdasarkan persamaan $\mathrm{LS}=0,2 \mathrm{~s}^{1,33}+0,1$, dimana $s$ merupakan panjang lereng. Berdasarkan persamaan tersebut dapat diperoleh nilai perhitunagn LS (Tabel 3) serta peta kelerengan yang ditunjukkan pada Gambar 2.

E. Indeks penutupan vegetasi dan pengolahan lahan

Nilai penutupan lahan (C) merupakan nilai perbandingan antara rata-rata tanah tererosi dari suatu lahan yang ditanami tanaman dan teknik

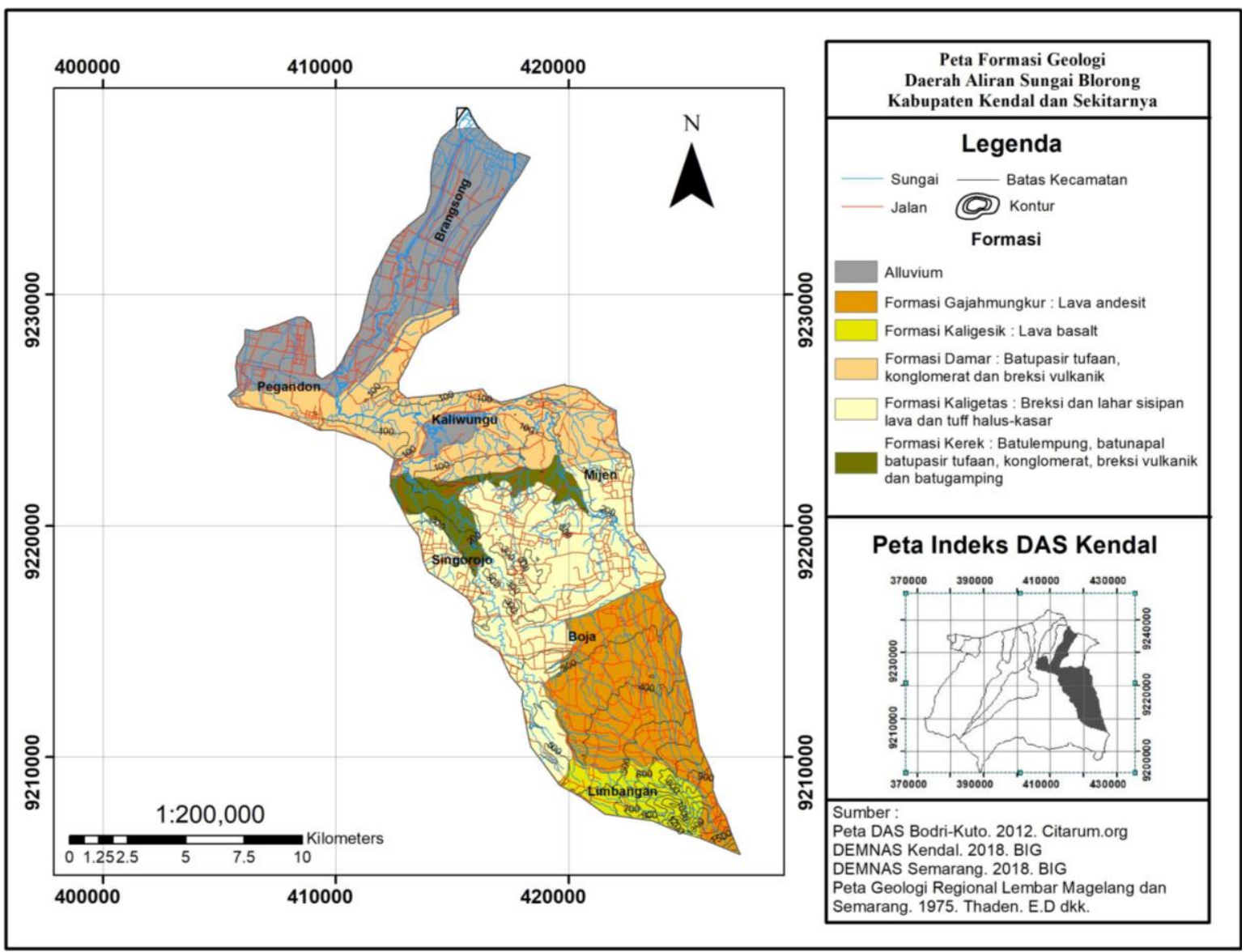

Gambar 3. Peta Geologi

Tabel 3. Nilai perhitungan indeks panjang dan kemiringan lereng (LS)

\begin{tabular}{ccccc}
\hline Kelerengan & Median (nilai tengah) & Nilai LS & Luas (HA) & Luas $\left(\mathrm{m}^{2}\right)$ \\
\hline $0-8$ & 4 & 1,364066099 & 12516.68291 & 125166828.6 \\
$9-15$ & 12 & 5,549304205 & 4866.82857 & 48668284.64 \\
$16-25$ & 20,5 & 11,20868446 & 2649.820882 & 26498208.11 \\
$26-45$ & 35,5 & 23,15864086 & 1219.512173 & 12195121.57 \\
$46-100$ & 73 & 60,2519069 & 400.225151 & 4002251.495 \\
\hline
\end{tabular}


pengolahan tertentu terhadap rata-rata tanah tererosi dari lahan yang tanpa tanaman pada tanah,lereng serta curah hujan yang sama. Pada lokasi penelitian nilai $\mathrm{C}$ diperoleh dengan membandingkan pola penutupan secara umum berdasarkan Wischmeier and Smith,1978. Nilai P atau tindakan konservasi yang terjadi pada lokasi penelitian memiliki nilai 0,5 untuk hutan, semak belukar dan kebun serta nilai 1 untuk pemukiman, sawah dan ladang (Tabel $4 \& 5)$.

F. Indeks tingkat bahaya erosi

Berdasarkan hasil dari perhitungan nilai laju erosi tanah Tabel $4 \& 5$ wilayah DAS Blorong termasuk kedalam kelas Tingkat Bahaya Erosi termasuk ke dalam kelas $\mathrm{V}$ dengan tingkat bahaya erosi sangat berat baik pada tahun 2013 maupun pada tahun 2018.

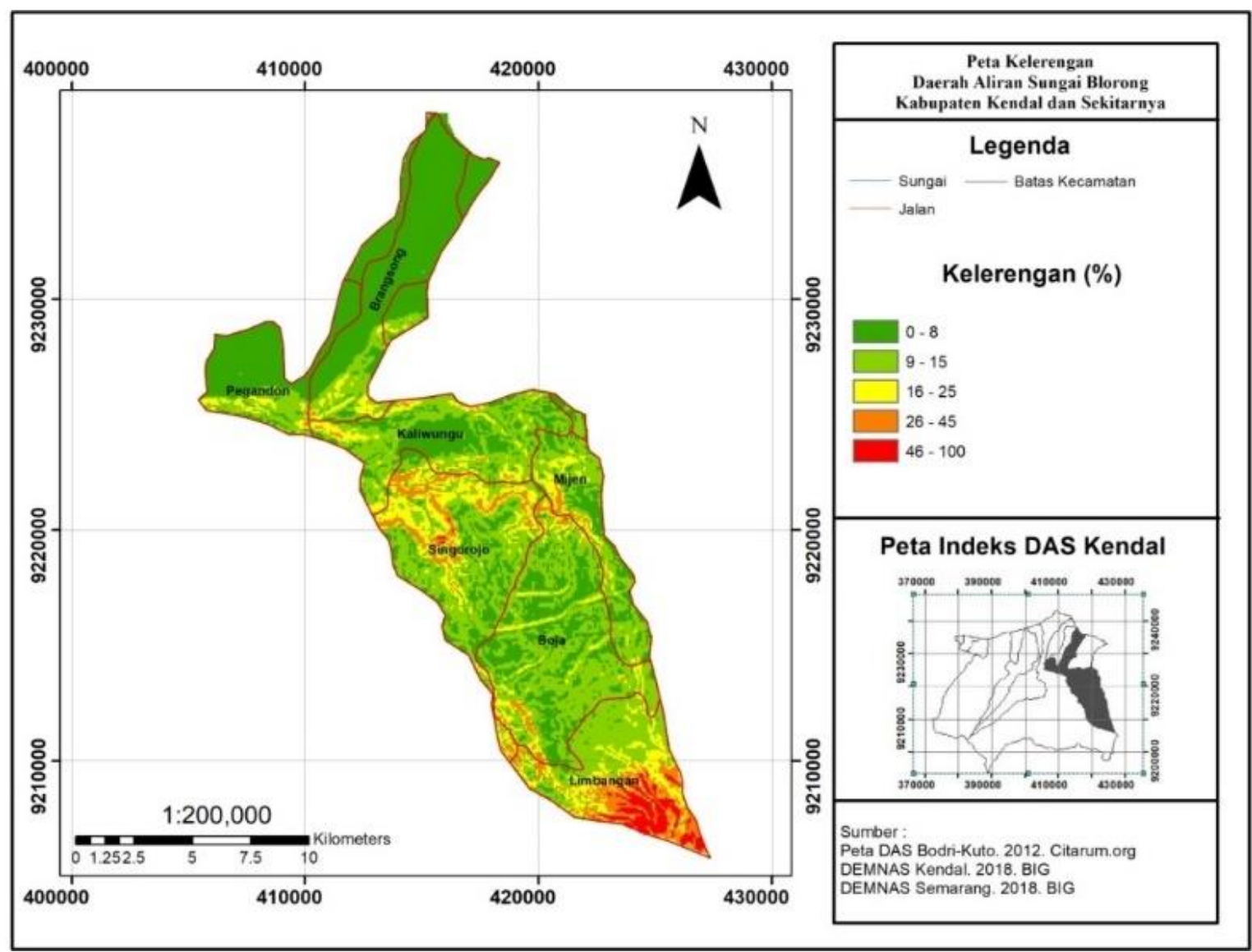

Gambar 4. Peta Kemiringan Lereng

Tabel 4. Perhitungan tingkat bahaya erosi Tahun 2013

\begin{tabular}{ccccccccc}
\hline $\begin{array}{c}\text { Tataguna } \\
\text { Lahan }\end{array}$ & $\begin{array}{c}\text { Klasifikasi } \\
\text { tanah }\end{array}$ & $\mathrm{K}$ & $\mathrm{C}$ & $\mathrm{LS}$ & $\mathrm{P}$ & $\begin{array}{c}\mathrm{R} \\
(2013)\end{array}$ & $\begin{array}{c}\text { Luas Wilayah } \\
(\mathrm{Ha})\end{array}$ & $\begin{array}{c}\text { Tingkat Erosi } \\
\text { ton/Ha/tahun } \\
(\mathrm{A})\end{array}$ \\
\hline Pemukiman & Loamy Sand & 0,12 & 1 & 1,36 & 1 & 235,8 & $2.719,74$ & $104.662,56$ \\
Sawah & Fine sand & 0,16 & 0,5 & 5,54 & 1 & 235,8 & $6.187,20$ & $646.602,99$ \\
Ladang & loamy sand & 0,12 & 0,078 & 11,2 & 1 & 235,8 & $1.748,96$ & $43.233,22$ \\
Hutan & fine sand & 0,16 & 0,001 & 23,15 & 0,5 & 235,8 & 81 & 35,34 \\
Semak & fine sand & 0,16 & 0,28 & 60,25 & 0,5 & 235,8 & 174,91 & $55.662,60$ \\
Belukar & Loamy sand & 0,12 & 0,012 & 11,2 & 0,5 & 235,8 & $1.072,61$ & $2.039,56$ \\
Kebun & \multicolumn{7}{c}{ Total Erosi } \\
\hline
\end{tabular}


Tabel 5. Perhitungan tingkat bahaya erosi Tahun 2018

\begin{tabular}{ccccccccc}
\hline $\begin{array}{c}\text { Tataguna } \\
\text { Lahan }\end{array}$ & $\begin{array}{c}\text { klasifikasi } \\
\text { tanah }\end{array}$ & $\mathrm{K}$ & $\mathrm{C}$ & $\mathrm{LS}$ & $\mathrm{P}$ & $\begin{array}{c}\mathrm{R} \\
(2018)\end{array}$ & $\begin{array}{c}\text { Luas Wilayah } \\
(\mathrm{Ha})\end{array}$ & $\begin{array}{c}\text { Tingkat Erosi } \\
\text { ton/Ha/tahun (A) }\end{array}$ \\
\hline Pemukiman & Loamy Sand & 0,12 & 1 & 1,36 & 1 & 261,2 & $2.719,74$ & $115.936,64$ \\
Sawah & Fine sand & 0,16 & 0,5 & 5,54 & 1 & 261,2 & $6.187,20$ & $716.254,03$ \\
Ladang & loamy sand & 0,12 & 0,078 & 11,2 & 1 & 261,2 & $1.748,96$ & $47.890,2298$ \\
Hutan & fine sand & 0,16 & 0,001 & 23,15 & 0,5 & 261,2 & 81 & 39,14 \\
Semak & fine sand & 0,16 & 0,28 & 60,25 & 0,5 & 261,2 & 174,91 & $61.658,49$ \\
Belukar & Loamy sand & 0,12 & 0,012 & 11,2 & 0,5 & 261,2 & $1.072,61$ & $2.259,26$ \\
Kebun & \multicolumn{1}{c}{ Total Erosi } \\
\hline
\end{tabular}

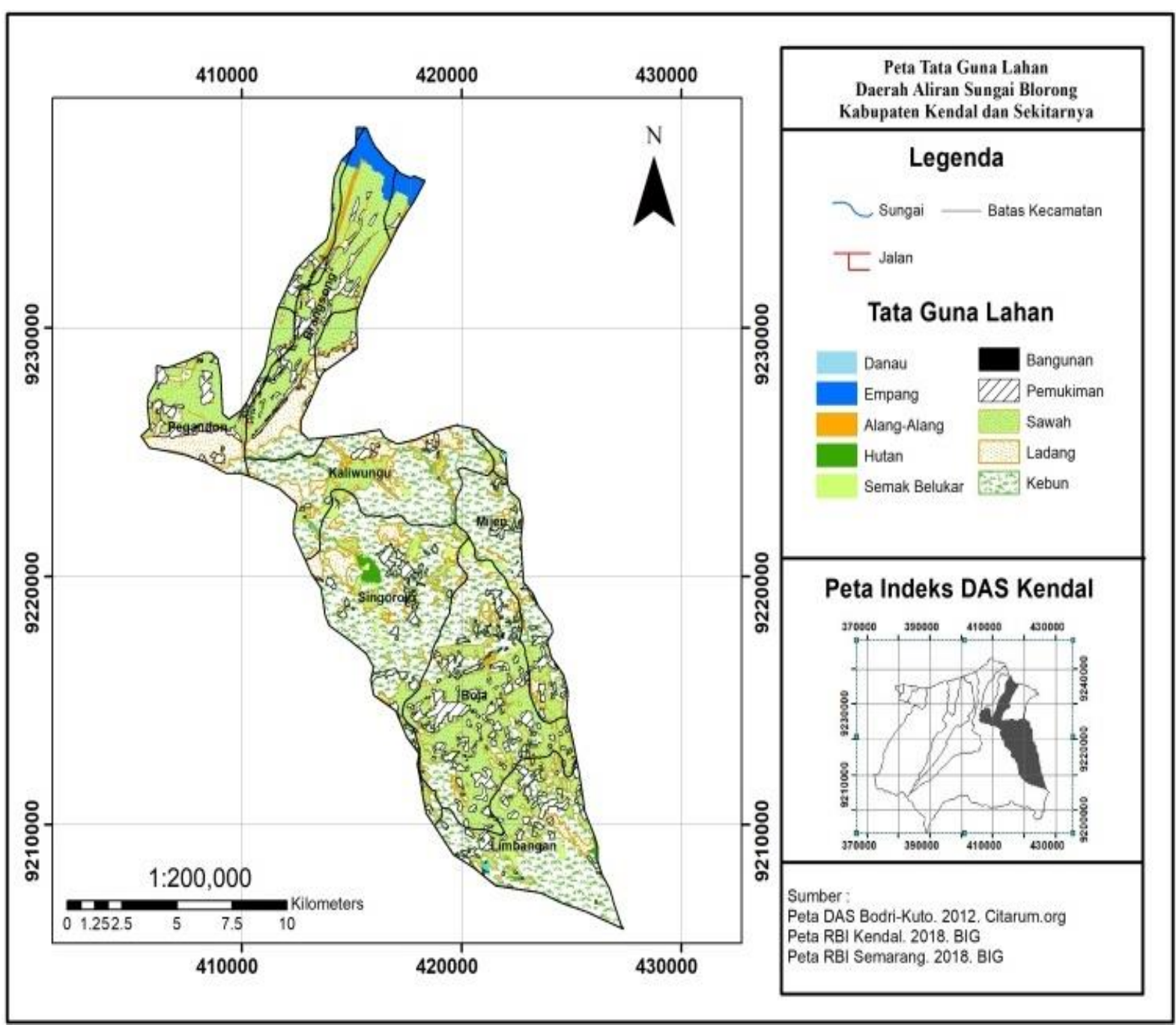

Gambar 5. Peta Tata Guna Lahan

\section{PEMBAHASAN}

Berdasarkan hasil analisis dalam penelitian ini, DAS Blorong dibagi ke dalam tiga bagian yaitu hulu, tengah, dan hilir. Setiap bagian memiliki karakteristik khusus ketika ditinjau dari parameter USLE.
1. DAS bagian Hulu

DAS Blorong yang berada di bagian hulu memiliki karakteristik fisik sebagai berikut. Memiliki bentuk DAS yang memanjang ditandai dengan adanya point bar pada sisi DAS. Luas DAS yang sempit karena berada pada dataran yang lebih tinggi dibanding dengan lokasi di 
sekitarnya, serta erosi yang bersifat vertikal menggerus bagian dalam DAS.

Litologi tersusun dari endapan alluvium yang terlihat dari adanya persawahan di sekitar lokasi, serta fragmen batuan beku berukuran bongkah yang menandakan bahwa batuan ini masih dekat dengan sumbernya. Kerapatan jaringan sungai tergolong sedang, karena jumlah anak sungai sedikit sehingga saat terjadi air limpasan permukaan air tersebut dapat tertampung ke anak-anak sungai. Lokasi sekitar DAS Blorong bagian hulu banyak digunakan sebagai persawahan karena adanya alluvium yang sangat cocok dalam pertumbuhan tanaman padi serta perkebunan dengan jenis tanaman tingkat tinggi yang homogen yang secara tidak langsung mampu membantu menahan air saat terjadi hujan.

\section{DAS bagian Tengah}

DAS Blorong yang berada di bagian tengah memiliki karakteristik sebagai berikut. Memiliki bentuk DAS yang memanjang ditandai dengan adanya point bar serta meander yang berada di sekitar sungai. Bentuk DAS yang memanjang ini menunjukkan bahwa daya tampung pada bagian tengah tidak terlalu besar. Luas daerah yang cukup besar yang diketahui bahwa pada bagian tengah berada di daerah yang cukup datar dengan topografi yang cukup rendah.

Litologi yang dijumpai berupa alluvium, batupasir, pasir, batulempung serta kerakalkerakal yang berukuran cukup besar. Kehadiran kerakal mengindikasikan bahwa lokasi DAS Blorong bagian tengah cukup jauh dari sumber. Kerapatan jaringan sungai tergolong rapat, terlihat dari banyaknya anak sungai yang ada. Anak sungai ini berperan dalam menerima limpasan air permukaan saat induk sungai sudah tidak mampu lagi menampungnya. Adapun daerah di sekitar DAS bagian tengah dimanfaatkan sebagai perkebunan untuk menanam tumbuhan seperti rumput gajah, persawahan serta banyaknya pasir yang membuat daerah DAS bagian tengah ini dijadikan sebagai salah satu tempat untuk menambang pasir.

\section{DAS bagian Hilir}

Pada DAS bagian hilir memiliki bentuk yang panjang ditandai dengan adanya point bar. Bentuk DAS yang panjang ini memiliki daya tempung tidak sebesar DAS yang memiliki bentuk lebar karena akumulasi untuk menampung pada DAS bagian hilir membutuhkan waktu yang cukup lama. Luas DAS memiliki luas kecil yang mempengaruhi debit pada DAS bagian hilir ini yaitu memiliki debit yang besar karena faktor losses. Topografi DAS bagian hilir terletak pada topografi yang rendah atau landai. Litologi yang dijumpai didominasi alluvium yang menyebabkan aliran permukaan yang besar. Kerapatan jaringan sungai yang besar ditandai dengan banyaknya anak sungai yang berperan menampung air limpasan saat sungai utama sudah mencapi batas. Tata guna lahan pada DAS bagian hilir paling banyak digunakan untuk persawahan selain itu juga digunakan sebagai tempat produksi batubata di sepanjang aliran, hal ini karena litologi yang ada disekitar DAS bagian hilir mendukung sebagai bahan baku batubata.

\section{A. Tingkat Erosi DAS Blorong}

Tingkat erosi DAS Blorong berdasarkan tata guna lahannya dibagi menjadi enam zona, yaitu pemukiman, sawah, ladang, hutan, semak belukar dan kebun. Selain itu dilakukan pula perbandingan tingkat erosi pada tahun 2013 dan 2018.

\section{Pemukiman}

Pada tata guna lahan pemukiman memiliki jenis tanah berupa loamy sand yang terlihat bahwa pasir lebih mendominasi daripada lempung pada daerah tersebut. memiliki nilai faktor erodibilitas tanah yang kecil yaitu 0.12 karena pada tanah jenis ini memiliki organic content yang sangat kecil. Faktor manajemen tanam pada pemukiman yang besar yaitu 1 . Kelerengan pada daerah pemukiman ini sekitar 4\% sehingga diperoleh nilai kelerengan sebesar 1,36. Adapun faktor praktek konservasi pada daerah pemukiman memiliki nilai 1 karena tidak adanya konservasi pada daerah tersebut. Nilai indeks erosivitas pemukiman pada tahun 2013 sebesar 235,8 sedangkan pada tahun 2018 sebesar 261,2 dengan luas wilayah 2.719,74 ha, maka dapat diketahui bahwa besarnya erosi pada daerah pemukiman pada tahun 2013 sebesar 104.662,55 ton/ha dan pada tahun 2018 sebesar 115.936,64 ton/ha.

2. Sawah

Pada tata guna lahan sawah memiliki jenis tanah berupa fine sand yang terlihat bahwa 
pada tata guna tersebut dijumpai pasir yang berukuran halus. Memiliki nilai faktor erodibilitas tanah yang cukup kecil yaitu 0,16 karena pada tanah jenis ini memiliki organic content yang sangat kecil. Faktor manajemen tanam pada sawah cukup besar yaitu 0,5 sebagaimana diketahui bahwa sawah tersebut masuh bersifat konvensioanl dalam pengelolannya. Kelerengan pada daerah pemukiman ini sekitar $12 \%$ sehingga diperoleh nilai kelerengan sebesar 5,54. Adapun faktor praktek konservasi pada sawah memiliki nilai 1 karena tidak adanya konservasi pada daerah tersebut. nilai indeks erosivitas pemukiman pada tahun 2013 sebesar 235,8 sedangkan pada tahun 2018 sebesar 261,2 dengan luas wilayah $6.187,20$ ha, maka dapat diketahui bahwa besarnya erosi pada daerah sawah pada tahun 2013 sebesar 646.602,98 ton/ha, pada tahun 2018 sebesar 716.254,03 ton/ha.

\section{Ladang}

Area dengan tata guna lahan ladang memiliki jenis tanah berupa loamy sand yang terlihat bahwa pasir lebih mendominasi daripada lempung pada daerah tersebut. memiliki nilai faktor erodibilitas tanah yang kecil yaitu 0,12 karena pada tanah jenis ini memiliki organic content yang sangat kecil. Faktor manajemen tanam pada ladang cukup besar yaitu 0,78 sebagaimana diketahui bahwa ladang tersebut masuh bersifat banyak tanaman yang berkayu. Kelerengan pada daerah pemukiman ini sekitar 20,5 \% sehingga diperoleh nilai kelerengan sebesar 11,2. Adapun faktor praktek konservasi pada ladang memiliki nilai 1 karena tidak adanya konservasi pada daerah tersebut. nilai indeks erosivitas pemukiman pada tahun 2013 sebesar 235,8 sedangkan pada tahun 2018 sebesar 261,2 dengan luas wilayah 1.748,96 ha, maka dapat diketahui bahwa besarnya erosi pada daerah ladang pada tahun 2013 sebesar 43.233,21 ton/ha dan pada tahun 2018 sebesar 47.890,22 ton/ha.

\section{Hutan}

Pada area tata guna lahan hutan memiliki jenis tanah berupa fine sand yang terlihat bahwa pada tata guna tersebut dijumpai pasir yang berukuran halus. Memiliki nilai faktor erodibilitas tanah yang sedang yaitu 0.12 karena pada tanah jenis ini memiliki organic content yang sangat kecil. Faktor manajemen tanam pada hutan cukup besar yaitu 0,001 karena pada hutan tersebut hampir keseluruhan tertutupi oleh pohon maupun kanopi. Kelerengan pada daerah pemukiman ini sekitar $35 \%$ sehingga diperoleh nilai kelerengan sebesar 23,15. Adapun faktor praktek konservasi pada hutan memiliki nilai 0,5 karena pada hutan tersebut dibuat terasering yang berguna untuk mengontrol laju erosi. Nilai indeks erosivitas pemukiman pada tahun 2013 sebesar 235,8 sedangkan pada tahun 2018 sebesar 261,2 dengan luas wilayah 81 ha, maka dapat diketahui bahwa besarnya erosi pada daerah ladang pada tahun 2013 sebesar 35,33 ton/ha, pada tahun 2018 sebesar 39,14 ton/ha.

\section{Semak Belukar}

Area dengan tata guna lahan semak belukar memiliki jenis tanah berupa fine sand yang terlihat bahwa pada tata guna tersebut dijumpai pasir yang berukuran halus. Memiliki nilai faktor erodibilitas tanah yang sedang yaitu 0.12 karena pada tanah jenis ini memiliki organic content yang sangat kecil. faktor manajemen tanam pada hutan cukup besar yaitu 0,28 karena pada semak belukar tersebut tertutupi oleh tumbuhan sebagian. Kelerengan pada daerah pemukiman ini sekitar $45 \%$ sehingga diperoleh nilai kelerengan sebesar 60,25 . Adapun faktor praktek konservasi pada hutan memiliki nilai 0,5 karena pada hutan tersebut dibuat terasering yang berguna untuk mengontrol laju erosi. Nilai indeks erosivitas pemukiman pada tahun 2013 sebesar 235,8 sedangkan pada tahun 2018 sebesar 261,2 dengan luas wilayah 174,91 ha, maka dapat diketahui bahwa besarnya erosi pada daerah ladang pada tahun 2013 sebesar 55662,60 ton/ha, pada tahun 2018 sebesar 61658,48 ton/ha.

6. Kebun

Pada tata guna lahan kebun memiliki jenis tanah berupa loamy sand yang terlihat bahwa pasir lebih mendominasi daripada lempung pada daerah tersebut. Memiliki nilai faktor erodibilitas tanah yang kecil yaitu 0.12 karena pada tanah jenis ini memiliki organic content yang sangat kecil. Faktor manajemen tanam pada ladang cukup besar yaitu 0,012 sebagaimana diketahui bahwa kebun tersebut 
hampir $80 \%$ tertutupi oleh tanaman. Kelerengan pada daerah pemukiman ini sekitar 20,5 \% sehingga diperoleh nilai kelerengan sebesar 11,2. Adapun faktor praktek konservasi pada ladang memiliki nilai 0,5 karena pada kebun tersebut dibuat terasering yang berguna untuk mengontrol laju erosi.. Nilai indeks erosivitas pemukiman pada tahun 2013 sebesar 235,8 sedangkan pada tahun 2018 sebesar 261,2 dengan luas wilayah 1072,61 ha, maka dapat diketahui bahwa besarnya erosi pada daerah ladang pada tahun 2013 sebesar 2039,55 ton/ha, pada tahun 2018 sebesar 2259,25 ton/ha.

Berdasarkan perolehan data tersebut total erosi yang terjadi di DAS Blorong pada tahun 2013 yaitu 852.236,26 ton/tahun sedangkan pada tahun 2018 sebesar 944.037,79 ton/tahun.

\section{KESIMPULAN}

Daerah Aliran Sungai Blorong berdasarkan karakteristik fisiknya (geometri kanal, litologi, dan kerapatan jaringan sungai) dapat dibagi menjadi 3 bagian yaitu bagian hulu, tengah dan hilir. Dari tahun 2013 ke tahun 2018 terjadi peningkatan laju erosi sebesar $10,78 \%$ yang dipengaruhi oleh nilai faktor erodibilitas yang semakin tinggi karena perbedaan intensitas curah hujan dan berubahnya tataguna lahan terutama lahan agrikultur, pemukiman, dan ladang yang kemudian menyebabkan Daerah Aliran Sungai (DAS) Blorong termasuk dalam tingkat erosi yang sangat tinggi. Rekomendasi yang dapat dilakukan untuk meminimalisir potensi erosi adalah berupa upaya konservasi pada wilayah ini, agar tingkat erosi dapat menurun.

\section{UCAPAN TERIMAKASIH}

Terima kasih kepada Departemen Teknologi UNDIP dan Dinas Pusdata Provinsi Jawa Tengah yang telah memberikan akses data untuk menyusun penelitian ini.

\section{DAFTAR PUSTAKA}

Anggoro, H.C., Suprayogi, I., Sujatmoko, B., 2018. Analisis Potensi erosi Das Galugua
Kecamatan Kapur IX Menggunakan Pendekatan USLE. Jom FTEKNIK 5 (2).

Ardiansyah, T., Lubis, K. S. dan Hanum, H., 2013. Kajian Tingkat Bahaya Erosi di Beberapa Penggunaan Lahan di Kawasan Hilir DAS Padang. Jurnal Agroekoteknologi Universitas Sumatera Utara, 2(1), 436-446.

Arsyad, S., 2006. Konservasi Tanah dan Air. Bandung: Penerbit IPB (IPB Press).

Badan Pusat Statistik Kabupaten Kendal, 2013. Kabupaten Kendal Dalam Angka 2013. Badan Pusat Statistik Kabupaten Kendal.

Badan Pusat Statistik Kabupaten Kendal, 2018. Kabupaten Kendal Dalam Angka 2018. Badan Pusat Statistik Kabupaten Kendal.

Hammer, W.I., 1981. Soil Conservation Consultant Report Center for Soil Research. LPT Bogor: Indonesia.

Kementerian Pekerjaan Umum. 2012. Java Erosion Model-USLE 30m: Application of the Universal Soil Loss Equation. Institutional Strenghthening for Integrated Water Resources Management (IWRM) in the 6 CI's River Basin Territory.

Oliveira, P. T. S., Wendland, E., dan Nearing, M. A. 2012. Rainfall erosivity in Brazil: A review, Catena, 100, 139-147.

Setyawan, C., Lee, C. Y. dan Prawitasari, M. 2017. Application Of GIS Software For Erosion Control In The Watershed Scale. International Journal of Scientific \& Technology Research, 6(1), 57-61.

Suripin. 2001. Pelestarian Sumber DayaTanah dan Air. Andi Offset.Yogyakarta.

Thaden, RE, Sumadirdja H, Richards.PW. 1996. Peta Geologi Lembar Magelang Semarang, Jawa. Direktorat Geologi, Bandung.

Wischmeier, W. H. dan Smith, D. 1978. Predicting rainfall erosion losses: a guide to conservation planning. USDA Agriculture Handbook No. 537.

Yin, S., Xie, Y., Liu, B., dan Nearing, M. A. 2015. Rainfall erosivity estimation based on rainfall data collected over a range of temporal resolutions. Hydrology and Earth System Sciences, 19(10), 4113-4126. https://doi.org/ 10.5194/hess-19-4113-2015 